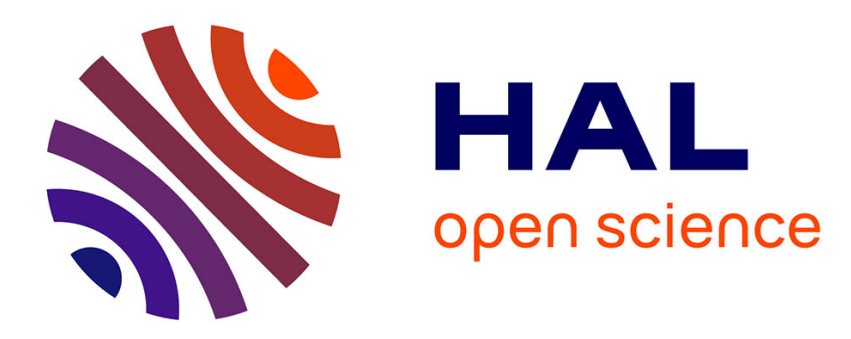

\title{
The mucinous variant of columnar cell lesions
}

\author{
Anoek Hj Maes, Paul van Diest
}

\section{To cite this version:}

Anoek Hj Maes, Paul van Diest. The mucinous variant of columnar cell lesions. Histopathology, 2011, 58 (6), pp.847. 10.1111/j.1365-2559.2011.03837.x . hal-00642273

\section{HAL Id: hal-00642273 https://hal.science/hal-00642273}

Submitted on 17 Nov 2011

HAL is a multi-disciplinary open access archive for the deposit and dissemination of scientific research documents, whether they are published or not. The documents may come from teaching and research institutions in France or abroad, or from public or private research centers.
L'archive ouverte pluridisciplinaire HAL, est destinée au dépôt et à la diffusion de documents scientifiques de niveau recherche, publiés ou non, émanant des établissements d'enseignement et de recherche français ou étrangers, des laboratoires publics ou privés. 


\section{Histopathology}

The mucinous variant of columnar cell lesions

\begin{tabular}{|r|l|}
\hline Journal: & Histopathology \\
\hline Manuscript ID: & HISTOP-01-10-0051.R1 \\
\hline Wiley - Manuscript type: & Original Article \\
\hline Date Submitted by the \\
Author: & 22-Mar-2010 \\
\hline Complete List of Authors: & $\begin{array}{l}\text { Maes, Anoek; University Medical Centre Utrecht, Pathology } \\
\text { van Diest, Paul; University Medical Center, Department of } \\
\text { Pathology }\end{array}$ \\
\hline Keywords: & $\begin{array}{l}\text { columnar cell lesions, flat epithelial atypia , mucinous, core needle } \\
\text { biopsy, breast }\end{array}$ \\
\hline \multicolumn{2}{|l}{} \\
\hline
\end{tabular}

\section{ScholarONE \\ Manuscript Central}




\section{The mucinous variant of columnar cell lesions}

Maes AHJ, Van Diest PJ

Department of Pathology, University Medical Center Utrecht

Address for correspondence:

Prof. Paul J van Diest, MD, PhD

Department of Pathology

University Medical Center Utrecht Cancer Center

PO Box 85500

3508 GA Utrecht

The Netherlands

Phone: $\quad+31887556565$

Fax $\quad+31302544990$

Key words: columnar cell lesions * flat epithelial atypia * mucinous * core needle biopsy * breast

Running title: mucinous columnar cell lesions of the breast 


\begin{abstract}
Aims: Mucin producing columnar cell lesion (CCL) is a rare new entity of the breast. This study describes the incidence and follow-up of mucinous CCLs.

Methods and results: In 4164 breast core needle biopsies (CNB), 291 showed a CCL and 21 atypical ductal hyperplasias originated in a CCL (ADH-CCL). Mucin production was present in 17 of 291 (5.8\%) CCLs and 3 of 21 (14.3\%) ADH-CCLs, together concerning 0.5\% of all CNBs. The most common mucinous CCL pattern was a columnar cell change without atypia and almost all were detected with microcalcifications as abnormality at mammography. During a median follow-up of 3.1 years, no invasive carcinoma or DCIS was detected. MUC2 was expressed in intraluminal mucin in 12 of 15 (80\%) mucinous CCLs and showed cytoplasmic expression in 5 of 15 (33\%) mucinous CCLs seen in CNBs. Moreover, mucinous CCLs were significantly more present in 46 mucinous carcinomas than in 46 ductal carcinomas ( $28 \%$ vs $9 \%$ ).

Conclusion: Mucinous CCLs are rare lesions with an incidence of about $0.5 \%$ of breast CNB, usually presenting with microcalcifications. Although these lesions might play a role in the mucinous progression spectrum, the short term risk of progression to more advanced lesions seems to be low.
\end{abstract}




\section{Introduction}

Mucinous lesions of the breast are rare. Although mucinous breast carcinomas have been recognized since $1816^{1}$, benign and premalignant mucinous lesions of the breast have only been described over the last few decades. A mucocele-like tumor was first described by Rosen in 1986 as multiple cysts with mucinous secretions lined by flattened or cuboid epithelium with cytologically bland cells, often showing extrusion of mucinous contents in the intervening stroma ("mucinous dissection") ${ }^{2}$. Other authors published variants of mucocelelike lesions in a morphological continuum with mucinous usual ductal hyperplasia (UDH), mucinous atypical ductal hyperplasia $(\mathrm{ADH})$, mucinous papillary lesions, mucinous ductal carcinoma in situ (DCIS) and mucinous or colloid carcinoma ${ }^{3-7}$.

Columnar cell lesions (CCLs) have recently drawn much attention as precursor lesions within the low nuclear grade breast cancer spectrum ${ }^{8-13}$ that are frequently diagnosed in breast screening programs as they are often associated with microcalcifications on mammography 3 , ${ }^{4,14-16}$. Only two case reports have described a mucocele like tumor and columnar cell hyperplasia occurring in a morphologic continuum ${ }^{17,18}$ and one paper has reported on mucin extravasation and mucocele-like lesions accompanying CCLs ${ }^{19}$, suggesting that the mucinous variant of CCL may be very rare. However, to the best of our knowledge, we are the first to systematically describe the incidence of mucin production in CCLs. Moreover, to study the possible precursor role of mucinous CCLs in the mucinous pathway towards mucinous carcinoma, we reviewed mucinous carcinomas for the presence of mucinous CCLs in the vicinity of the invasive cancer and compared them to ductal carcinomas.

The breast always produces mucins, but most of them are membrane bound. In mucinous lesions, there is a switch from membrane bound mucin towards the production of secreted gel forming mucins ${ }^{20,21}$. Mucins are high molecular-weight glycoproteins expressed by different types of epithelium and can be categorized into two groups: membrane bound (MUC1, MUC3A, MUC3B, MUC4, MUC12, MUC13, MUC17) and secreted or gel forming (MUC2, MUC5AC, MUC5B, MUC6) ${ }^{22,23}$. Of all MUC genes, MUC2 has been described to be most discriminating between mucinous and ductal invasive carcinomas and the most frequently expressed in mucinous carcinomas, playing a major role in the production of the extracellular mucin ${ }^{21,23-26}$. Besides, O'Connell et al. described MUC2 expression of cells in mucinous DCIS, ADH and UDH in the vicinity of mucinous carcinoma as well, implying that the 
altered mucin expression in these lesions precedes mucinous carcinoma ${ }^{25}$. Therefore, we also investigated MUC2 expression for our mucinous CCLs. 


\section{Methods}

Using the Dutch pathology archiving system (PALGA), all breast core needle biopsies (CNB) from women were identified from the archives of the University Medical Centre of Utrecht (UMCU) from January 2001 until May 2008 (except for 2006 because these slides were misplaced), from the Rivierenland Hospital Tiel (RHT) between 2001 until 2005; from the Antonius Hospital Nieuwegein (AHN), and from the Mesos Hospital Utrecht (MHU) from 2002 until 2006, in The Netherlands.

The CNBs were performed under ultrasound or stereotactic guidance, using 14-gauge needles in the UMCU, RHT, and AHN. In the MHU, 16 to 18-gauge and sporadically 11-gauge (with Mammotome) were used. We reviewed the mammography records to ascertain the reason for taking the CNB: density, microcalcifications or both. In densities group, also palpable masses, architectural distortions and asymmetries were included.

\section{Histology}

All original hematoxylin-and-eosin-stained (H\&E) slides from the CNBs were reviewed by two experienced observers (AM and PJVD) and scored for presence of CCLs and atypical ductal hyperplasia originating in a CCL (ADH-CCL). CCLs were classified into four categories according to Schnitt and Vincent-Salomon: columnar cell change (CCC), columnar cell hyperplasia $(\mathrm{CCH}), \mathrm{CCC}$ with atypia and $\mathrm{CCH}$ with atypia ${ }^{12}$. CCLs are variably enlarged terminal duct lobular units (TDLU), lined by enlarged columnar cells with only one or two layers of columnar type epithelium in CCC. The cells contain elongated nuclei, with an orientation along the basement membrane and containing inconspicuous or absent nucleoli. Apical snouts are often present, frequently showing intraluminal secretions and microcalcifications. $\mathrm{CCH}$ has a similar appearance as $\mathrm{CCC}$, but the TDLUs are lined by more than two stratified cell layers. In $\mathrm{CCC}$ with atypia (CCC-A) and $\mathrm{CCH}$ with atypia (CCH-A), cytonuclear atypia is superimposed showing relatively round or ovoid (instead of elongated) not regularly orientated nuclei. The nuclei mostly have an irregular shape, often with prominent nucleoli. According to the WHO criteria ${ }^{27,27}$, lesions with enlarged ducts with complex architectural patterns with arcades, bridging or micropapillae were considered as ADH or low-grade DCIS, depending on the size of the lesion and the extent of the architectural complexity and regularity. ADH lesions arising in the context of a CCL (ADH$\mathrm{CCL}$ ) were noted, as these lesions might represent a further step in the progression of CCLs to 
$\mathrm{ADH}$ and low grade DCIS. Moreover, the presence of microcalcifications in the CCLs was noted in each specimen.

All CCLs were reviewed again to ascertain the presence of mucin in the lesion. For the definition mucinous CCL, we used the following criteria. At first, a columnar cell lesion has to be present as described above, comprising the largest part of the lesion. Secondly, mucin must be seen in the centre of the TDLU, often combined with extravasation of the mucin in the surrounding stroma (mucinous dissection) (Figure 1). A Periodic Acid-Schiff or Alcian blue staining can be used to confirm the presence of mucin. See Figure 1, 2 and 3 for examples of mucinous CCC, mucinous $\mathrm{CCH}$ and mucinous ADH-CCL. The lesion has to be differentiated from a mucocele-like tumour that has (one layer of) flattened or cuboid lining epithelium. Other lesions in the differential diagnosis are mucinous atypical ductal hyperplasia and mucinous DCIS, exhibiting both the characteristic architectural and cytological atypia according to the usual criteria ${ }^{27}$, in combination with mucin in the cysts or $\operatorname{ducts}^{3,28,29}$.

Mucinous CCLs in mucinous versus ductal carcinomas cases

From the UMCU archive, we retrieved surgical resection specimens of 46 pure mucinous carcinoma cases diagnosed between 1990 and 2009 and 46 consecutive invasive ductal carcinoma cases from January 2009 onwards. The slides were reviewed (by AM and PJvD) and scored for the presence of CCL with or without intraluminal mucin.

\section{Immunohistochemistry}

Mucinous CCLs with sufficient material left in the CNB blocks were stained with the BondMax Autostainer, using the mouse monoclonal antibody MUC2 (Santa Cruz, H-300, 1:400). Appropriate positive and negative controls were used throughout. MUC2 was scored for the (stained) intraluminal mucin and presence of cells with intracytoplasmic staining.

\section{Electron microscopy}

One mucinous columnar cell lesion was chosen for evaluation by electron microscopy according to usual procedures for processing paraffin material. 


\section{Follow-up}

We obtained follow-up information from all cases until November 2009 by a search in the local and national PALGA Pathology databases and hospital information systems for the last performed mammography and last moment of follow-up. The national PALGA searches reveal pathology reports from all Dutch pathology labs, making sure we would not miss a more advanced lesion in the follow up diagnosed in other centers. The H\&E slides of the subsequent surgical excision biopsies from the mucinous CCLs were reviewed by the same observers (AM and PJvD). We noted the presence of a mucinous columnar cell lesion or other lesions in these excisions. Besides, in the subsequent surgical excision biopsies of all other CCL cases in the initial CNBs (apart from those with the mucinous variant), we looked for mucinous CCLs. It was noted for which CCLs invasive carcinoma or DCIS had occurred in the past. 


\section{$\underline{\text { Results }}$}

A total number of 4164 breast CNBs were reviewed. Table 1 shows the numbers of CCLs and $\mathrm{ADH}-\mathrm{CCL}$ and the abnormalities at mammography leading to these CNBs. As summarized in Table 2, 17 mucinous CCLs of which 3 with atypia were found in 17 women as well as 3 mucinous ADH-CCL in 2 women (overall frequency 20/4164=0.5\%). Mucinous dissection was present in 18 out of $20(90 \%)$ of these lesions. All of them were associated with microcalcifications at mammography (one combined with a density), and these microcalcifications were mostly recognized in the CCL at histology as well. The mean age of these women was 53.9 years (range 36 to 74 years).

Luminal mucin was confirmed by Alcian blue staining (Figure 4), and PAS-D staining showed the presence of intracytoplasmic mucin as well (Figure 5). Electron microscopy of this part of the specimen confirmed the presence of many intracytoplasmic vacuoles with a sharp boundary (Figure 6). Assuming these are filled with mucin, this suggests that intracellular mucin in the columnar cells may be the origin of the intraluminal mucin.

Moreover, MUC2 was expressed in the intraluminal mucin in 12 of $15(80 \%)$ mucinous CCLs (Table 3, Figure 7) and showed cytoplasmic expression in some cells in 5 of 15 (33\%) mucinous CCLs seen in CNBs.

Mucinous CCL was significantly more frequent $(13 / 46,28 \%)$ in mucinous carcinomas cases than in ductal carcinoma cases $(4 / 46,9 \%)(p=0.004)$ (Figure 8). Atypical CCLs (CCL-A or ADH-CCL, both mucinous and non-mucinous CCLs) were more frequent in mucinous invasive carcinoma cases $(14 / 19,74 \%)$ compared to ductal carcinomas $(8 / 19,42 \%)(p=$ 0.049).

Three women (two with mucinous $\mathrm{CCH}-\mathrm{A}$ and one with mucinous $\mathrm{CCH}$ in the $\mathrm{CNB}$ ) underwent a surgical excision biopsy between 1 and 7 months. In two of the three follow up surgical excisions, $\mathrm{CCH}-\mathrm{A}$ without mucin was found, and in one a mucinous $\mathrm{CCH}$. During the follow-up period (mean 3.1 years, range 0.5 to 7 years), no invasive carcinoma or DCIS occurred.

Next to the subsequent excision biopsies of the mucinous CCLs in the CNBs, 68 other excision biopsies were performed of the remaining 292 CCLs and ADH-CCLs. Of these 68, five showed a mucinous CCL in the excision (1 CCC, 2 CCH, 2 CCL-A) with in one also atypical lobular neoplasia. One subsequent invasive ductal carcinoma of intermediate grade with intermediate grade DCIS showed a mucinous CCL with atypia as well. In one case, invasive lobular carcinoma had preceded the mucinous CCL four years before. 


\section{$\underline{\text { Discussion }}$}

This is the first study that systematically describes the incidence of mucinous CCL in breast CNB. 17 mucinous CCLs of 291 CCLs (5.8\%) and 3 mucinous ADH-CCL of 21 ADH-CCL (14.4\%) were found, together concerning $0.5 \%$ of all breast CNB. Coyne et al and Fadare et al ${ }^{17,18}$ were the first ones who both described such lesions in single case reports before, suggesting a potential relationship giving their coexistence and the morphologic transitions between the lesions. Begum et al ${ }^{19}$ has reported about the coexistence of CCLs with mucin extravasation and mucocele-like lesions as well. Besides, mucocele-like lesions have been the subject of several other studies, often presented in coexistence with other entities like mucinous usual ductal hyperplasia, ADH, DCIS through to mucinous carcinoma ${ }^{3,5,7,29}$. These lesions are postulated to represent a morphologic and biologic spectrum ${ }^{5,7,15}$. So possibly an evolutionary pathway could be present from benign mucinous lesions to invasive mucinous carcinomas, just like described by Abdel-Fatah for the tubular and lobular carcinomas on the basis of histological evidence and reported genetic changes ${ }^{30}$. In these pathways, CCLs (especially those with atypia) seem to play an important role, which can be hypothesized to be true for mucinous CCLs in the mucinous pathway as well. Indeed, in the study described by Begum et al ${ }^{19}$, DCIS was found in a few excision biopsies with CCL and mucin extravasation in the initial CNBs. We have not been able to demonstrate development of mucinous DCIS or invasive mucinous cancer (or other types of DCIS or invasive cancer) from mucinous CCL in our series. This may be related to the low number of mucinous CCL patients, the relatively short follow-up interval and the fact that only very few mucinous CCLs were treated by surgical excision biopsy.

We found significantly more mucinous CCLs in mucinous carcinoma cases than in ductal carcinoma cases, confirming that mucinous CCLs indeed might be important in the developmental pathway towards mucinous carcinoma. This is underlined by the fact that CCLs (both mucinous and non-mucinous) were more frequently atypical in mucinous than in ductal carcinoma cases.

MUC2 is typically expressed in the cytoplasm of tumour cells in mucinous carcinoma ${ }^{21,23-26 \text {, }}$ ${ }^{31}$ and we found MUC2 expressing cells in 5 of 15 (33\%) mucinous CCL cases as well. In concordance with our finding, O'Connell et al. ${ }^{25}$ described positive cells in mucinous DCIS, $\mathrm{ADH}$ and UDH surrounding mucinous carcinoma. Also "normal epithelium" was described to show expression, but on review of the figures of "normal epithelium" in their 1999 paper we 
would suggest that this in fact concerns a columnar cell lesion. We have never seen MUC2 luminal or intracytroplasmic staining in normal breast tissue. These data suggest that changes like MUC2 expression already occur in precursor lesions. We also found intraluminal mucin staining in the present study, whereas other studies using other antibodies did not show this staining pattern. This indicates that different MUC2 antibody clones can provide different staining patterns ${ }^{21,23-26,31}$.

We showed that the mucinous CCLs are typically biopsied for microcalcifications as abnormality on mammography, which has been described for mucocele-like lesions by others as well $^{3,4,14-16,29,32}$. Columnar cell lesions in general also present by microcalcifications, which may further suggest a relationship in the origin of the lesions with both unfolded TDLU.

It is yet not fully clear what the implications are of finding a mucinous CCL in a CNB. For mucocele-like lesions found on CNB it has been suggested that excision should follow to exclude the presence of invasive carcinoma ${ }^{33}$, although others suggest that CNBs represent such lesions reliably ${ }^{34,35}$. For columnar cell lesions with atypia, excision biopsies are usually recommended, and for those without atypia only follow-up is advised ${ }^{11}$. Since we did not find any events during follow up, we do not suggest any other approach for mucinous CCL until further studies better address the natural course of mucinous CCLs.

In conclusion, mucinous CCL and mucinous $\mathrm{ADH}-\mathrm{CCL}$ are rare lesions occurring in about $0.5 \%$ of breast $\mathrm{CNB}$, usually presenting during the usual age range with microcalcifications. These lesions might play a role in the mucinous progression spectrum, which is underlined by the high incidence of mucinous CCLs in mucinous carcinoma cases. Although further studies are needed to more extensively explore the natural course of these lesions, the short term progression risk seems to be low. 
Table 1 Number of core needle biopsies (CNBs) and mammographic abnormalities of columnar cell lesions (CCLs) and atypical hyperplasia originating in CCL (ADH-CCLs)

\begin{tabular}{|l|l|}
\hline & Number of cases (\%) \\
\hline Total number of CNB & 4164 \\
\hline Total number of CCLs & 291 \\
\hline Total number of ADH-CCL & 21 \\
\hline & \\
\hline $\begin{array}{l}\text { Abnormalities at mammography } \\
\text { (for both CCL and ADH-CCL): }\end{array}$ & 70 \\
\hline Density & 210 \\
\hline Microcalcifications & 32 \\
\hline Both &
\end{tabular}


Table 2 Nature of mucinous columnar cell lesions (CCL) found in a consecutive series of 4164 breast core needle biopsies and accompanying mammographic abnormalities $(\mathrm{CCC}=$ columnar cell change, $\mathrm{CCH}$-columnar cell hyperplasia; $\mathrm{CCL}-\mathrm{A}=\mathrm{CCL}$ with atypia; ADH-CCL, atypical ductal hyperplasia originating in a CCL)

\begin{tabular}{|l|c|}
\hline & $\begin{array}{l}\text { Number of } \\
\text { cases }(\%)\end{array}$ \\
\hline Number of mucinous CCLs and ADH-CCL & $20(100 \%)$ \\
\hline - Mucinous CCC & $10(50 \%)$ \\
\hline - Mucinous CCH & $4(20 \%)$ \\
\hline - Mucinous CCL-A & $3(15 \%)$ \\
\hline - Mucinous ADH-CCL & $3(15 \%)$ \\
\hline & $18(90 \%)$ \\
\hline Extravasation of mucin in stroma & $18(90 \%)$ \\
\hline Calcification in mucinous cysts at histology & \\
\hline & \\
\hline Abnormalities at mammography & $0(0 \%)$ \\
\hline - Density & $19(95 \%)$ \\
\hline - Microcalcifications & $15 \%)$ \\
\hline - Both & \\
\hline
\end{tabular}


Table 3 Frequency of mucinous and non-mucinous CCLs in 46 mucinous versus 46 invasive ductal carcinoma cases of the breast

\begin{tabular}{|l|r|r|r|}
\hline & $\begin{array}{r}\text { Ductal } \\
\text { carcinoma }\end{array}$ & $\begin{array}{r}\text { Mucinous } \\
\text { carcinoma }\end{array}$ & $\begin{array}{r}\text { Chi-square } \\
\text { test }\end{array}$ \\
\hline Non-mucinous CCL & 15 & 6 & $p=0.004$ \\
\hline Mucinous CCL & 4 & 13 & \\
\hline Total & 19 & 19 & \\
\hline
\end{tabular}


Table 4 Expression of MUC2 in 15 CCLs of different grade seen in breast core needle biopsies

\begin{tabular}{|l|l|l|l|l|}
\hline & \multicolumn{2}{|c|}{ Intraluminal mucin } & \multicolumn{2}{c|}{ Cytoplasmic expression } \\
\hline & - & + & - & + \\
\hline Mucinous CCC & 2 & 5 & 5 & 2 \\
\hline Mucinous CCH & 0 & 3 & 3 & 0 \\
\hline Mucinous CCL-A & 1 & 1 & 2 & 0 \\
\hline Mucinous ADH-CCL & 0 & 3 & 0 & 3 \\
\hline Total & 3 & $12(80 \%)$ & 10 & $5(33 \%)$ \\
\hline
\end{tabular}


Fig. 1 Mucinous columnar cell change of the breast with mucinous dissection (20x)

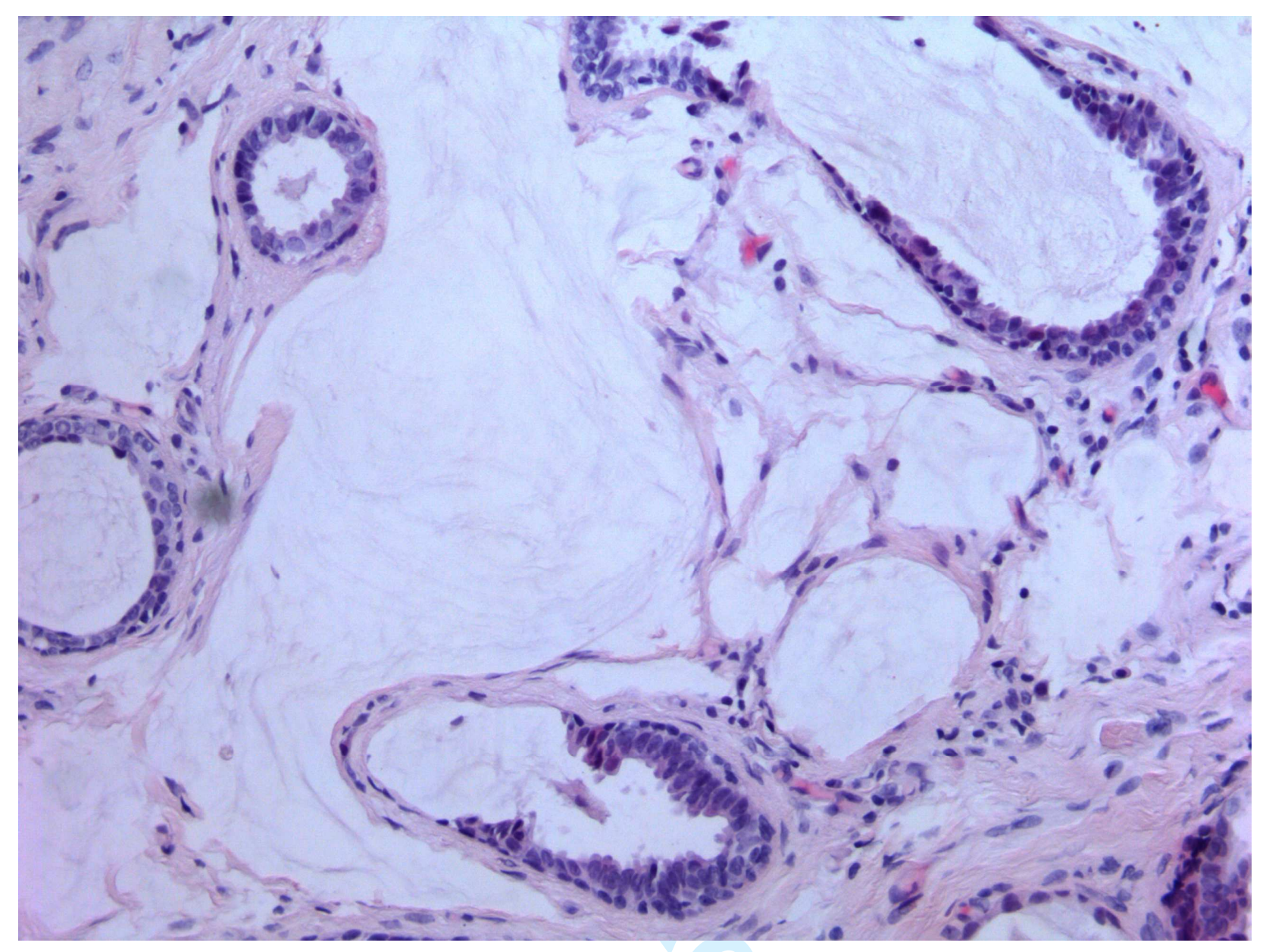


Fig. 2 Mucinous columnar cell hyperplasia (20x)

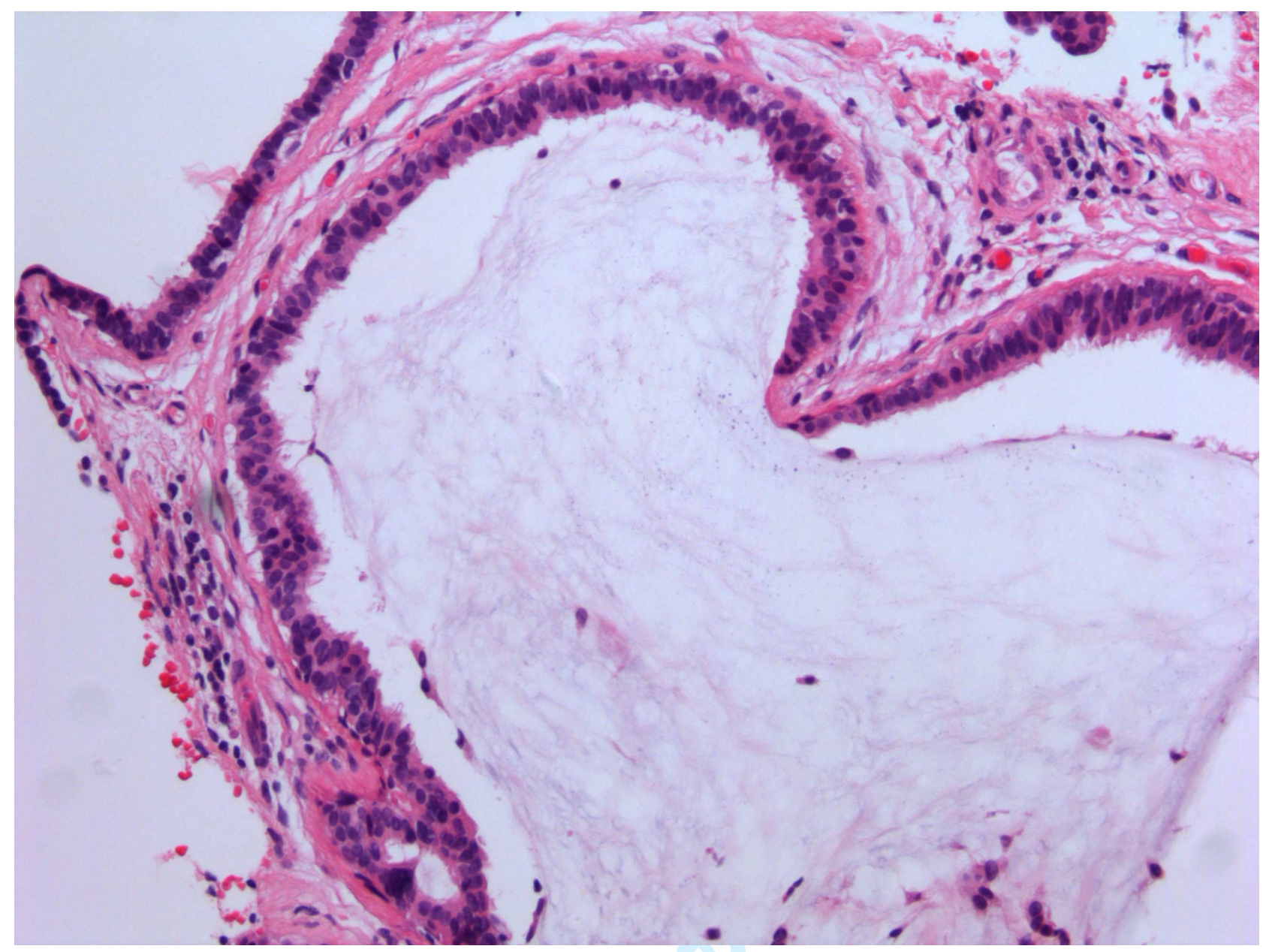


Fig. 3 Mucinous atypical ductal hyperplasia originating in a CCL (ADH-CCL) (10x)

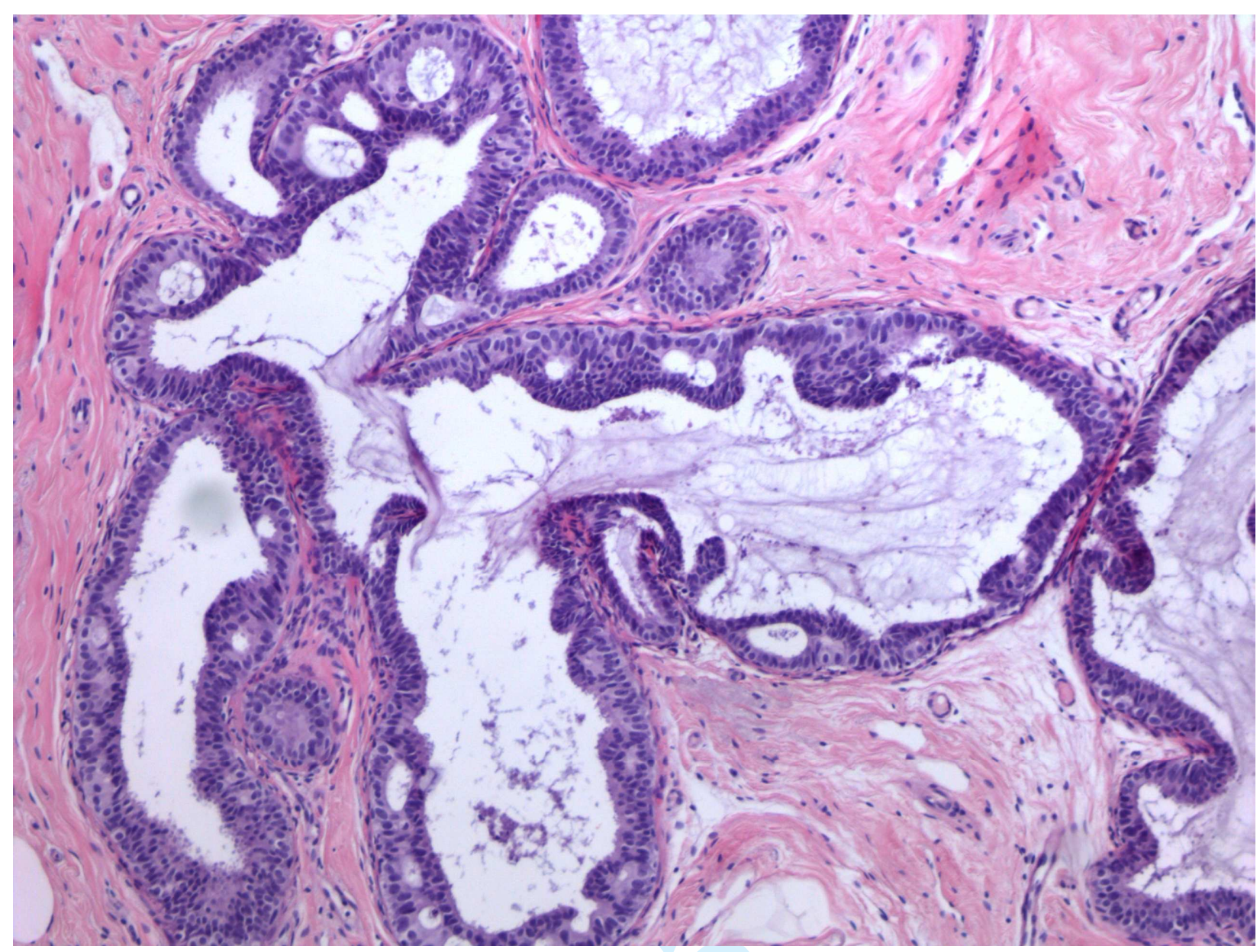


Fig. 4 Alcian blue staining of a mucinous columnar cell hyperplasia. The blue colour confirms the presence of intraluminal mucin.

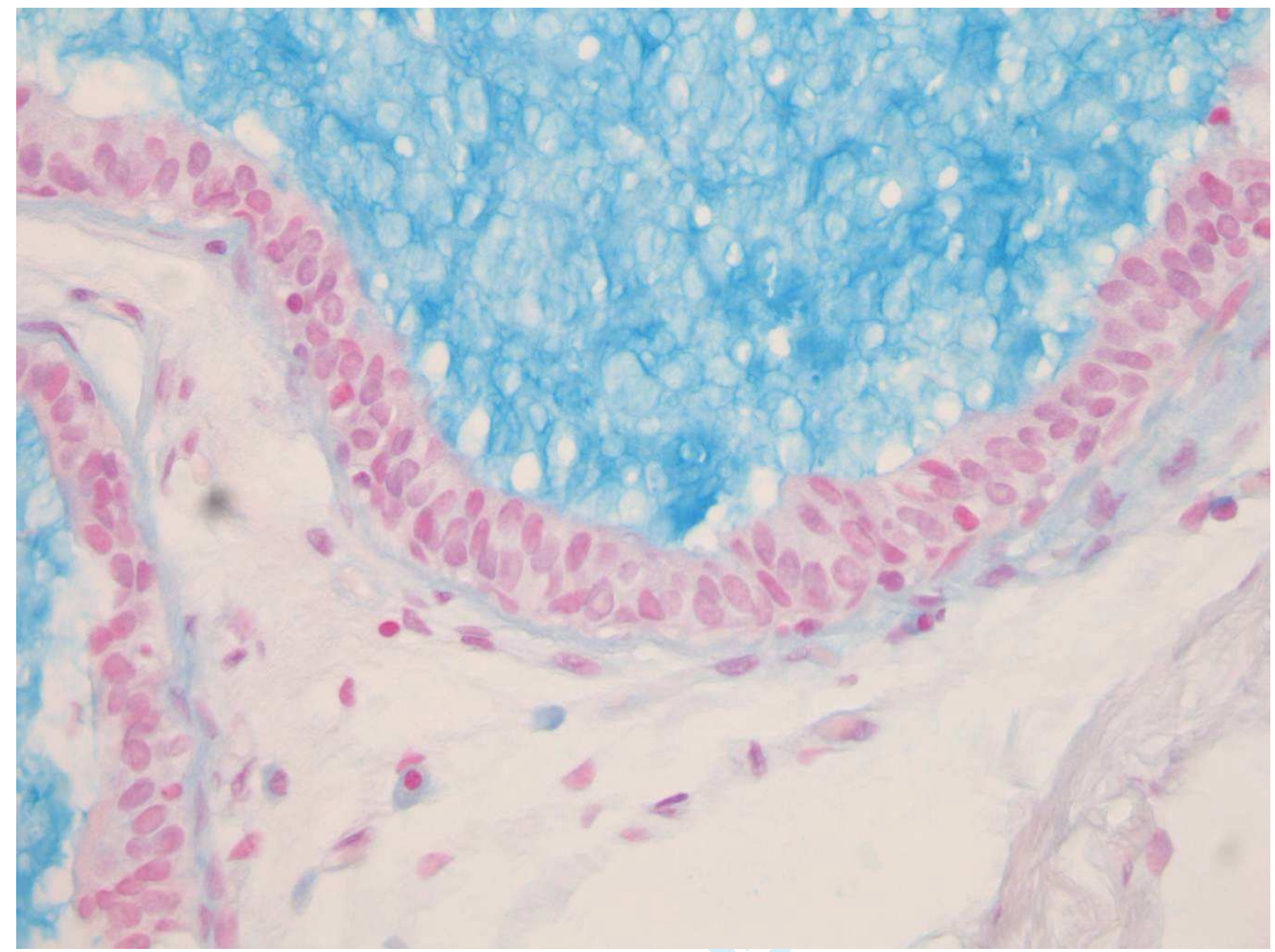


Fig. 5 PAS-D staining of a mucinous columnar cell hyperplasia (the deep red-purple colour shows the intraluminal mucin). The arrows indicate the presence of intracytoplasmic vacuoles filled with mucin.

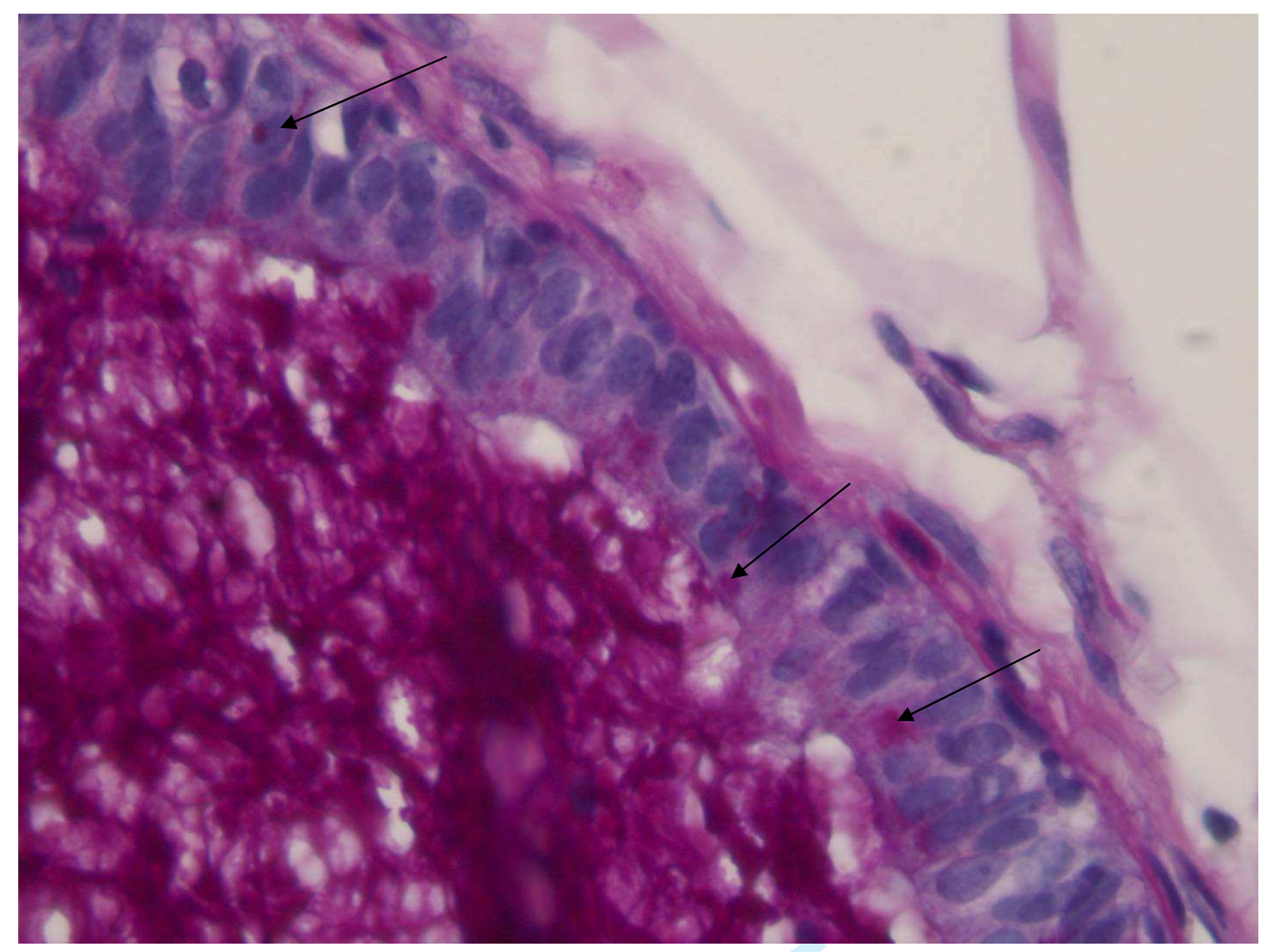


Fig. 6 Electron microscopy picture of a mucinous columnar cell lesion showing intracytoplasmic vacuoles (see arrows) with a sharp boundary, corresponding to those shown in figure 5 that were filled with mucin

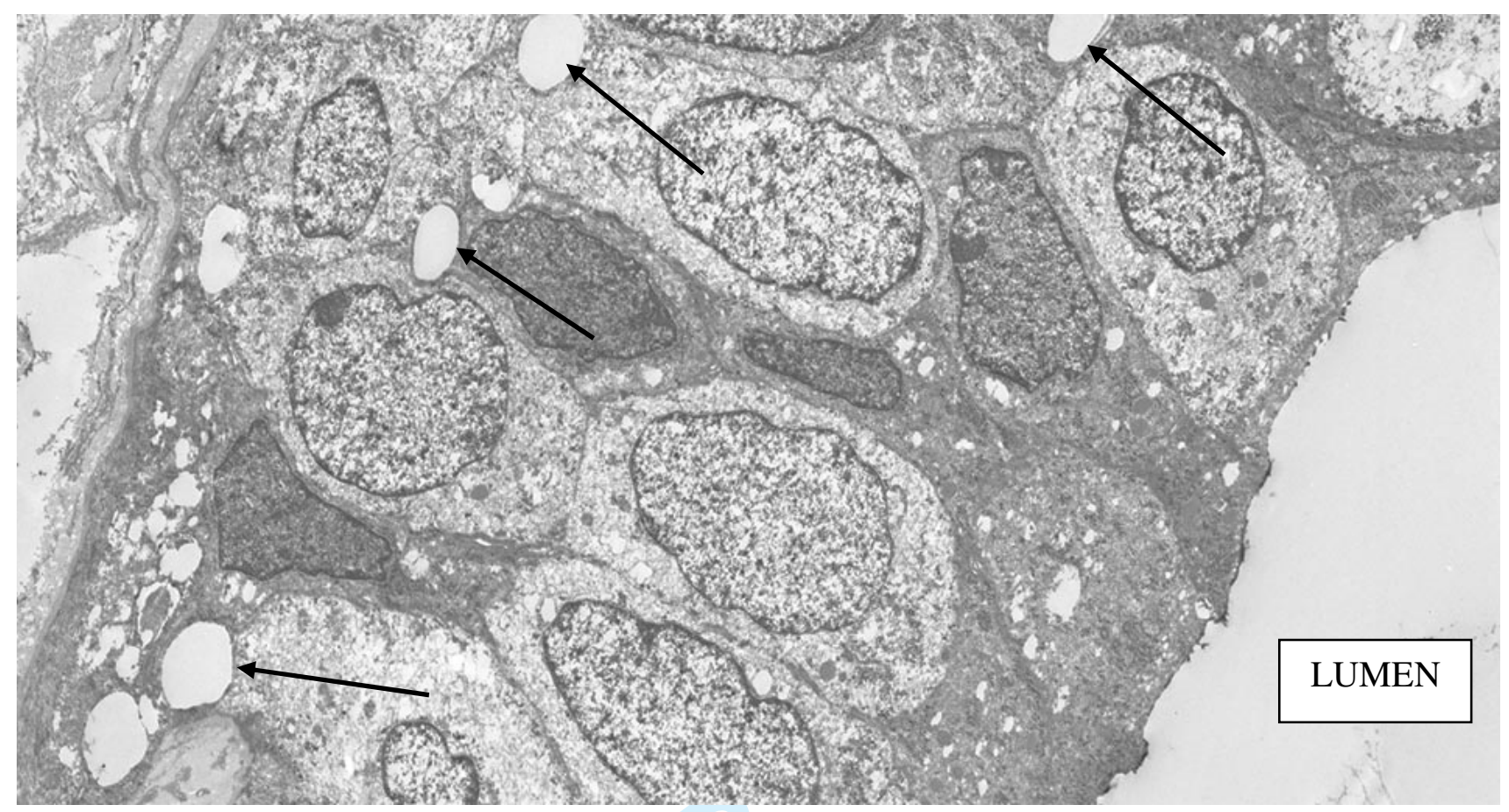


Figure 7 Mucinous CCL with MUC2 staining showing the intraluminal positivity of the mucin and cells with intracytoplasmic staining (20x)

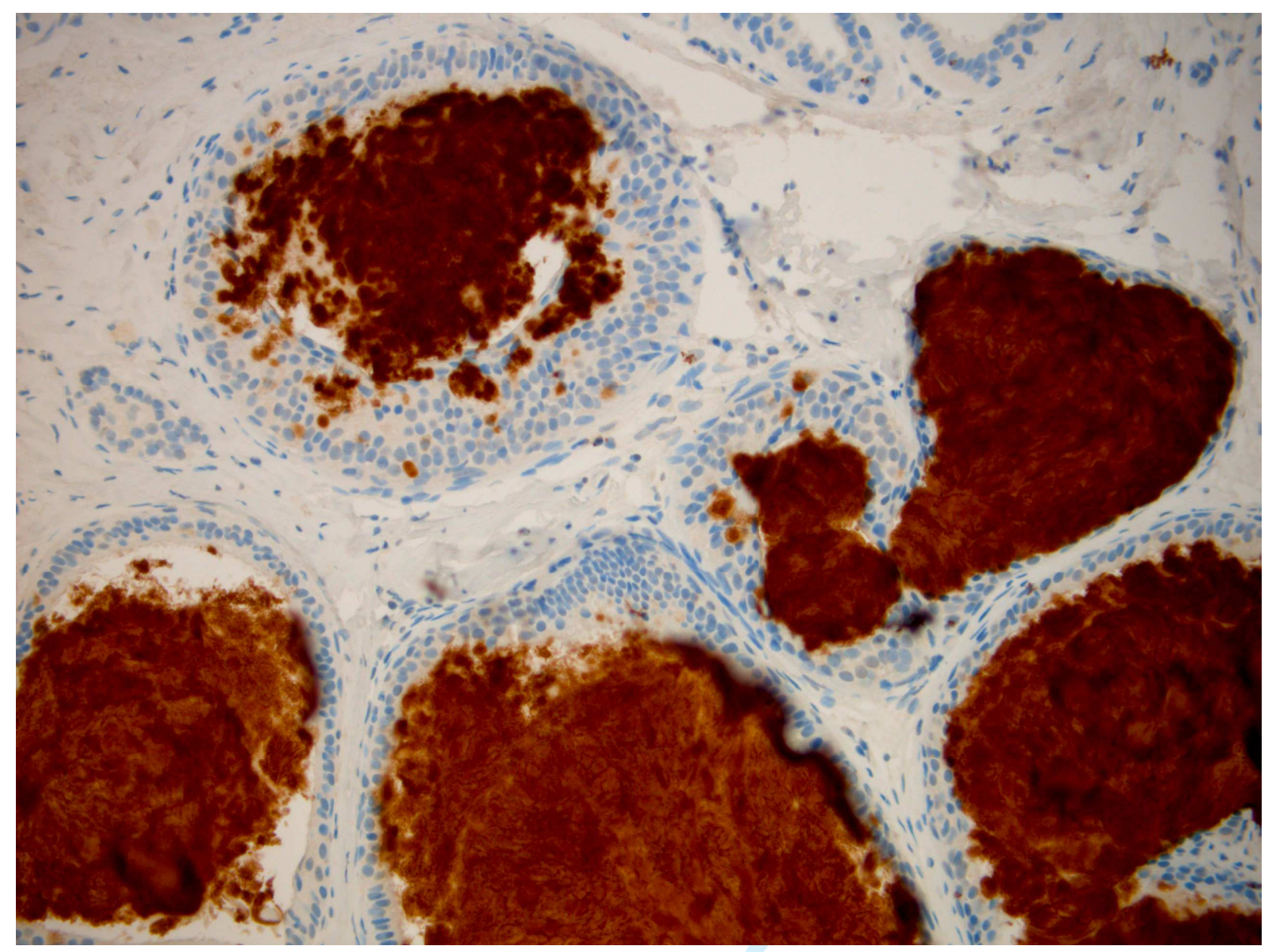


Figure 8 Mucinous columnar cell hyperplasia (bottom right) next to invasive mucinous carcinoma (top left, top right) (10x)

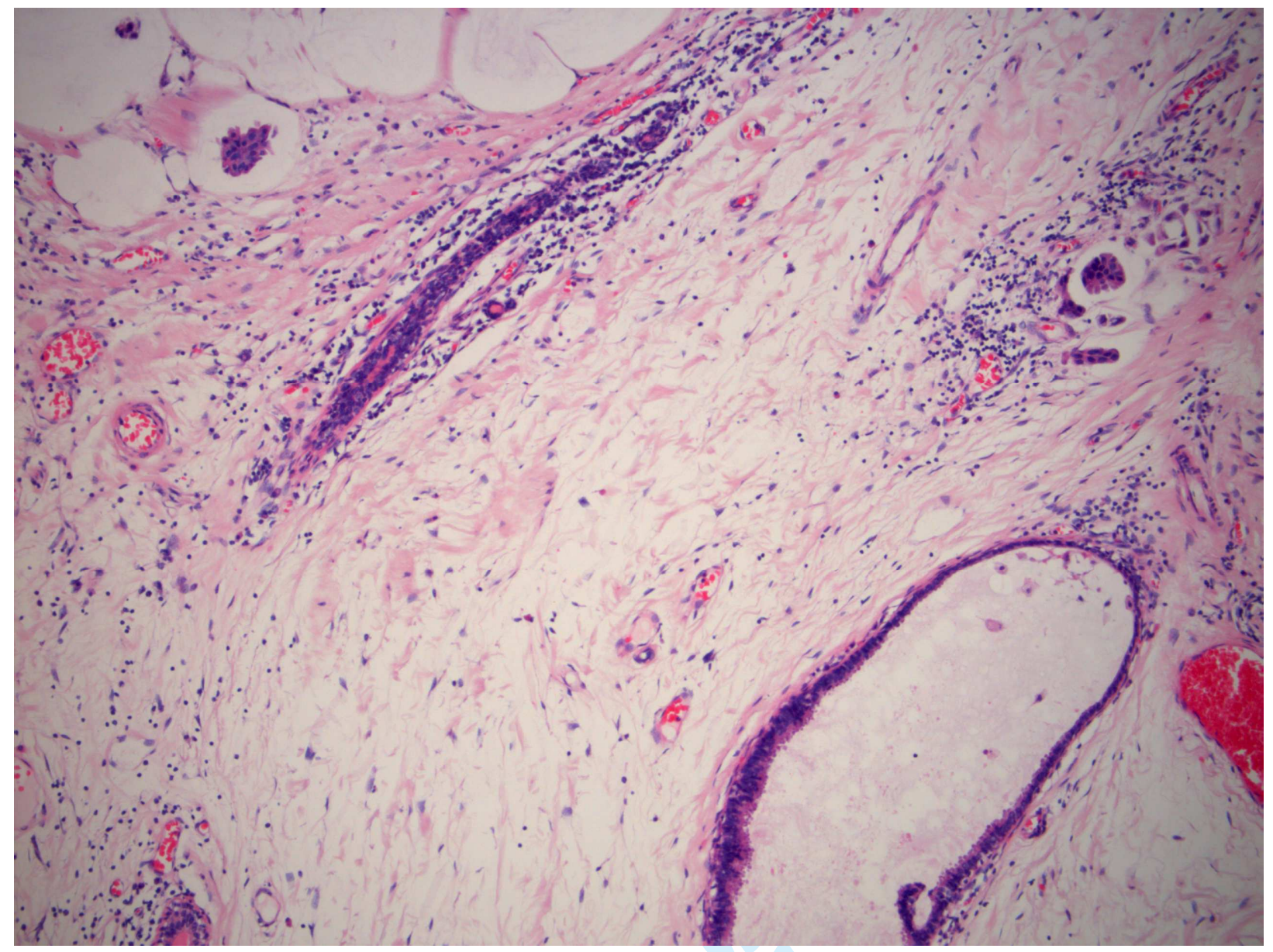




\section{$\underline{\text { Reference List }}$}

1. Geschickter CF. Gelatinous mammary cancer. Ann. of Surgery 1938;108(3):321-346.

2. Rosen PP. Mucocele-like tumors of the breast. Am. J. Surg. Pathol. 1986 Jul;10(7):464469.

3. Chinyama CN, Davies JD. Mammary mucinous lesions: congeners, prevalence and important pathological associations. Histopathology 1996 Dec;29(6):533-539.

4. Farshid G, Pieterse S, King JM, Robinson J. Mucocele-like lesions of the breast: a benign cause for indeterminate or suspicious mammographic microcalcifications. Breast J. 2005 Jan;11(1):15-22.

5. Ro JY, Sneige N, Sahin AA, Silva EG, del Junco GW, Ayala AG. Mucocelelike tumor of the breast associated with atypical ductal hyperplasia or mucinous carcinoma. A clinicopathologic study of seven cases. Arch. Pathol. Lab Med. 1991 Feb;115(2):137140 .

6. Tan PH, Tse GM, Bay BH. Mucinous breast lesions: diagnostic challenges. J Clin Pathol. 2008 Jan;61(1):11-19.

7. Weaver MG, bdul-Karim FW, al-Kaisi N. Mucinous lesions of the breast. A pathological continuum. Pathol. Res. Pract. 1993 Sep;189(8):873-876.

8. Aulmann S, Elsawaf Z, Penzel R, Schirmacher P, Sinn HP. Invasive Tubular Carcinoma of the Breast Frequently is Clonally Related to Flat Epithelial Atypia and Low-grade Ductal Carcinoma In Situ. Am. J. Surg. Pathol. 2009 Aug 11.

9. Dabbs DJ, Carter G, Fudge M, Peng Y, Swalsky P, Finkelstein S. Molecular alterations in columnar cell lesions of the breast. Mod. Pathol. 2006 Mar;19(3):344-349.

10. Dessauvagie BF, Zhao W, Heel-Miller KA, et al. Characterization of columnar cell lesions of the breast: immunophenotypic analysis of columnar alteration of lobules with prominent apical snouts and secretions. Hum Pathol. 2007 Feb;38(2):284-292.

11. Feeley L, Quinn CM. Columnar cell lesions of the breast. Histopathology 2008 Jan;52(1):11-19.

12. Schnitt SJ, Vincent-Salomon A. Columnar cell lesions of the breast. Adv Anat. Pathol. 2003 May;10(3):113-124.

13. Simpson PT, Gale T, Reis-Filho JS, et al. Columnar cell lesions of the breast: the missing link in breast cancer progression? A morphological and molecular analysis. Am J Surg Pathol. 2005 Jun;29(6):734-746.

14. Kim JY, Han BK, Choe YH, Ko YH. Benign and malignant mucocele-like tumors of the breast: mammographic and sonographic appearances. Am. J. Roentgenol. 2005 Nov;185(5):1310-1316. 
15. Leibman AJ, Staeger CN, Charney DA. Mucocelelike lesions of the breast: mammographic findings with pathologic correlation. Am. J. Roentgenol. 2006 May;186(5):1356-1360.

16. Tanaka K, Komoike Y, Egawa $\mathrm{C}$, et al. Indeterminate calcification and clustered cystic lesions are strongly predictive of the presence of mucocele-like tumor of the breast: a report of six cases. Breast Cancer 2009;16(1):77-82.

17. Coyne JD. Columnar cell hyperplasia with intraluminal crystalloids and features of a mucocoele-like lesion. Histopathology 2004 Apr;44(4):401-403.

18. Fadare O, Mariappan MR. Mucocele-like tumor and columnar cell hyperplasia of the breast occurring in a morphologic continuum. J. Med. Case. Reports. 2008;2:138.

19. Begum SM, Jara-Lazaro AR, Thike AA, et al. Mucin extravasation in breast core biopsies--clinical significance and outcome correlation. Histopathology 2009 Nov;55(5):609-617.

20. Kim YS, Gum JR, Jr. Diversity of mucin genes, structure, function, and expression. Gastroenterology 1995 Sep;109(3):999-1001.

21. Matsukita S, Nomoto M, Kitajima S, et al. Expression of mucins (MUC1, MUC2, MUC5AC and MUC6) in mucinous carcinoma of the breast: comparison with invasive ductal carcinoma. Histopathology 2003 Jan;42(1):26-36.

22. Diaz LK, Wiley EL, Morrow M. Expression of epithelial mucins Muc1, Muc2, and Muc3 in ductal carcinoma in situ of the breast. Breast J. 2001 Jan;7(1):40-45.

23. Rakha EA, Boyce RW, bd El-Rehim D, et al. Expression of mucins (MUC1, MUC2, MUC3, MUC4, MUC5AC and MUC6) and their prognostic significance in human breast cancer. Mod. Pathol. 2005 Oct;18(10):1295-1304.

24. Adsay NV, Merati K, Nassar H, et al. Pathogenesis of colloid (pure mucinous) carcinoma of exocrine organs: Coupling of gel-forming mucin (MUC2) production with altered cell polarity and abnormal cell-stroma interaction may be the key factor in the morphogenesis and indolent behavior of colloid carcinoma in the breast and pancreas. Am. J. Surg. Pathol. 2003 May;27(5):571-578.

25. O'Connell JT, Shao ZM, Drori E, Basbaum CB, Barsky SH. Altered mucin expression is a field change that accompanies mucinous (colloid) breast carcinoma histogenesis. Hum. Pathol. 1998 Dec;29(12):1517-1523.

26. Chu JS, Chang KJ. Mucin expression in mucinous carcinoma and other invasive carcinomas of the breast. Cancer Lett. 1999 Jul 19;142(1):121-127.

27. Tavassoli FA, Devilee P. WHO Classification Tumours of the Breast and Female Genital Organs. IARC, Lyon, 2003.

28. Carder PJ, Murphy CE, Liston JC. Surgical excision is warranted following a core biopsy diagnosis of mucocoele-like lesion of the breast. Histopathology 2004 Aug;:45(2):148-154. 
29. Hamele-Bena D, Cranor ML, Rosen PP. Mammary mucocele-like lesions. Benign and malignant. Am. J. Surg. Pathol. 1996 Sep;20(9):1081-1085.

30. Abdel-Fatah TM, Powe DG, Hodi Z, et al. Morphologic and molecular evolutionary pathways of low nuclear grade invasive breast cancers and their putative precursor lesions: further evidence to support the concept of low nuclear grade breast neoplasia family. Am J Surg Pathol. 2008 Apr;32(4):513-523.

31. Yonezawa S, Sato E. Expression of mucin antigens in human cancers and its relationship with malignancy potential. Pathol. Int. 1997 Dec;47(12):813-830.

32. Glazebrook K, Reynolds C. Original report. Mucocele-like tumors of the breast: mammographic and sonographic appearances. Am. J. Roentgenol. 2003 Apr;180(4):949954.

33. Jacobs TW, Connolly JL, Schnitt SJ. Nonmalignant lesions in breast core needle biopsies: to excise or not to excise? Am J Surg Pathol. 2002 Sep;26(9):1095-1110.

34. Renshaw AA, Cartagena N, Schenkman RH, Derhagopian RP, Gould EW. Atypical ductal hyperplasia in breast core needle biopsies: Correlation of size of the lesion, complete removal of the lesion, and the incidence of carcinoma in follow-up biopsies. Am. J. Clin. Pathol. 2001 Jul;116(1):92-96.

35. Wang J, Simsir A, Mercado C, Cangiarella J. Can core biopsy reliably diagnose mucinous lesions of the breast? Am. J. Clin. Pathol. 2007 Jan;127(1):124-127. 
Colour Work Agreement Form Form No: SN_Upw2000_P_CoW_F2

(WV) WILEY-

WLACKWELL

\begin{abstract}
If you have any problems or queries please contact the Production Editor for guidance (details can be found in the Instructions for Authors)

If you have submitted a manuscript that contains colour figures, it is the policy of the journal for authors to meet the full cost of colour reproduction. Blackwell Publishing require you to complete this form. Please fill in your contact details and then complete the table as instructed. Note: this form must be filled in for all manuscripts that have been submitted with colou work, even if you subsequently choose not to publish either in print or online in colour.
\end{abstract}

We are unable to process your manuscript until we receive your instructions so please return this form as quickly as possible!

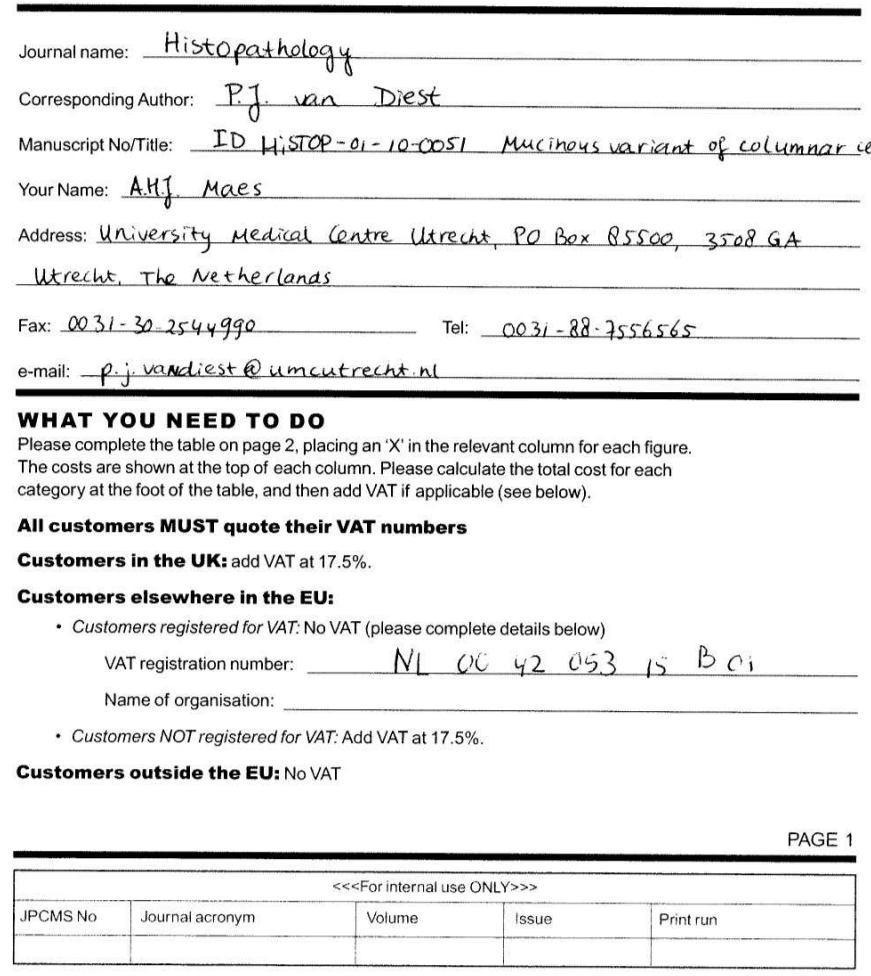


Please now complete this table (Remember: only one ' $X$ ' per figure).

\begin{tabular}{|l|l|l|l|}
\hline Figure Number & $\begin{array}{l}\text { Column 1 } \\
\text { Colour in print and online }\end{array}$ & $\begin{array}{l}\text { Column 2 } \\
\text { Colour online ONLY }\end{array}$ & $\begin{array}{l}\text { Column 3 } \\
\text { Black \& white in print and online }\end{array}$ \\
\hline Costs & $\begin{array}{l}\text { 1st and 2nd figures }=\text { Free } \\
\text { Subsequent figures }=\text { £60 each }\end{array}$ & £50 each & Free \\
\hline 1 & $X$ & & \\
\hline 2 & $x$ & & \\
\hline 3 & $x$ & & \\
\hline 4 & $x$ & & \\
\hline 5 & $x$ & & \\
\hline 6 & $x$ & & \\
\hline 7 & $x$ & & \\
\hline 8 & & & 1 \\
\hline 9 & 7 & & \\
\hline 10 & & & \\
\hline $\begin{array}{l}\text { Total number of } \\
\text { figures of each type }\end{array}$ & & & \\
\hline
\end{tabular}

\begin{tabular}{|ll|ll|}
\hline \multicolumn{4}{|c|}{ Quick costlookup table for colour figures in print and online: } \\
\hline No. of colour figs & Cost & No. of colour figs & Cost \\
\hline 1 & Free & 6 & $£ 240$ \\
2 & Free & 7 & $£ 300$ \\
3 & $£ 60$ & 8 & $£ 360$ \\
4 & $£ 120$ & 9 & $£ 420$ \\
5 & $£ 180$ & 10 & $£ 480$ \\
\hline
\end{tabular}

\author{
Column 1 total $£ \_300$ \\ Column 2 total $£$ \\ VAT (if applicable) $£$ \\ Total: $\mathbf{E}$
}

Payment by Credit Card (MasterCard/VISA/American Express)

Blackwell Publishing accepts payment in three major currencies:

Pounds Sterling, United States Dollars and the Euro. Please indicate which currency you would like to pay in:

Pounds Sterling (₹) $\square /$ United States Dollars* (US\$) $\square /$ Euros* $^{*}(€) \square$ (tick one)

*Conversions from US $\$$ or will be made at our monthly rate.

Please debit my credit card number: \begin{tabular}{|l|l|l|l|l|l|l|l|l|l|l|l|l|l|l|l|}
\hline 5 & 4 & 7 & 5 & 9 & 1 & 0 & 4 & 8 & 4 & 0 & 1 & 6 & 8 & 6 & 0 \\
\hline
\end{tabular}

Verification ID Number: \begin{tabular}{|l|l|l|}
\hline 0 & 4 & 2 \\
\hline
\end{tabular}

7 This can be found on your credit card (Visamastercaron have 3 numbers and $A$ max has 4 )

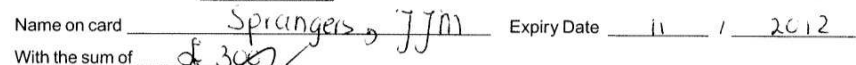
$\begin{array}{llll}\text { With the sum of } & \text { Signature } \\ \text { Note: payment by cre of co d can only be accepted if all sections are completed. }\end{array}$ Please use BLOCK CAPJyal S where possible.

Payment by Purchlase Order

If you are asking your university or institution to pay we require purchase order details

lattach order number

dated

Please now return all pages of your completed form as a scanned electronic file (preferred option), or by fax or post to the production editor for your journal.

Contact details can be found in the instructions for authors. 